\title{
Pharmacological Characterization of the Novel Anxiolytic $\beta$-Carboline Abecarnil in Rodents and Primates
}

\author{
Masaki Ozawa ${ }^{1}$, Yukie Nakada ${ }^{1}$, Keiko Sugimachi $^{1}$, Fumie Yabuuchi ${ }^{1}$, Tetsuo Akai ${ }^{1}$, \\ Eiji Mizuta ${ }^{2}$, Sadako Kuno ${ }^{2}$ and Motonori Yamaguchi ${ }^{1, *}$ \\ ${ }^{I}$ Research Department, Nihon Schering K.K., 2-6-64, Nishimiyahara, Yodogawa-ku, Osaka 532, Japan \\ ${ }^{2}$ Department of Neurology, Center for Neurological Disease, Utano National Hospital, Narutaki, Kyoto 616, Japan
}

Received Octaber 15, 1993 Accepted December 18, 1993

\begin{abstract}
Carboline abecarnil was behaviorally and biochemically characterized as a new anxiolytic agent in rodents and primates in comparison with the benzodiazepine (BZ) anxiolytics. Oral treatment with abecarnil $(0.5-10 \mathrm{mg} / \mathrm{kg})$ showed a potent anticonflict activity in the water-lick test in rats. The minimal effective dose was lower than those of BZ anxiolytics, such as etizolam, diazepam, clotiazepam and tofisopam. Abecarnil also showed taming effects to suppress fighting and aggressive behaviors in mice and monkeys with little sedative and ataxic effects, in contrast to the $\mathrm{BZ}$ anxiolytics producing marked sedative and ataxic effects. Furthermore, abecarnil suppressed both the sedative and ataxic effects induced by diazepam. Abecarnil bound to rat cerebellar $B Z_{1}$ receptors $\left(K_{i}=0.24 \mathrm{nM}\right)$ with a higher affinity than to rat spinal cord $B Z_{2}$ receptors $\left(K_{i}=1.3 \mathrm{nM}\right)$, whereas $B Z$ derivatives bound to both the receptors with a low and equal affinity. GABA-ratios of abecarnil were 1.9 for the $\mathrm{BZ}_{1}$ receptors and 2.8 for the $\mathrm{BZ}_{2}$ receptors, and they were smaller than those of diazepam and flunitrazepam. Thus, in contrast to the BZ derivatives, abecarnil may act as a selective partial agonist at central $\mathrm{BZ}_{1}$ receptors, resulting in its potent anticonflict and taming effects with little sedative and ataxic effects.
\end{abstract}

Keywords: Abecarnil, Anxiolytic, $\beta$-Carboline, Benzodiazepines, GABA

Benzodiazepines (BZs) as effective anxiolytics have been the most widely used drugs in the treatment of anxiety disorders. However, BZs have been reported to show unwanted side effects such as sedation, ataxia and amnesia. The development of tolerance and dependence also have arisen as unwanted features in the long-term use of BZs as anxiolytics. For these reasons, the drug development in this field recently has been directed to the search for a new anxiolytic without unwanted side effects.

Abecarnil (ZK 112119; isopropyl 6-benzyloxy-4-methoxymethyl- $\beta$-carboline-3-carboxylate, Fig. 1) has been developed as a new anxiolytic with an advantageous pharmacological profile over BZs (1). Previous biochemical and pharmacological studies have indicated that abecarnil acts as a partial agonist at central BZ receptors with a high binding affinity and exerts marked anxiolytic and anticonvulsant actions, but in contrast to diazepam, only weak or no sedative and ataxic effects $(1-4)$. In addition, there was no development of tolerance to the anticonvul-

\footnotetext{
* To whom correspondence should be addressed.
}

sant effects of abecarnil in dogs in contrast to BZs (5).

On the other hand, there are known to be at least three types of $\mathrm{BZ}$ receptors, $\mathrm{BZ}_{1}$ (type-I), $\mathrm{BZ}_{2}$ (type-II) and $\mathrm{BZ}_{\mathrm{P}}$ (peripheral type) in mouse, rat, monkey and human brain $(6-9) . \mathrm{BZ}_{1}$ and $\mathrm{BZ}_{2}$ receptors, which are termed central $B Z$ receptors, are associated with the $\mathrm{GABA}_{\mathrm{A}} / \mathrm{BZ}$ receptor complex and modulate the GABA neuronal function.

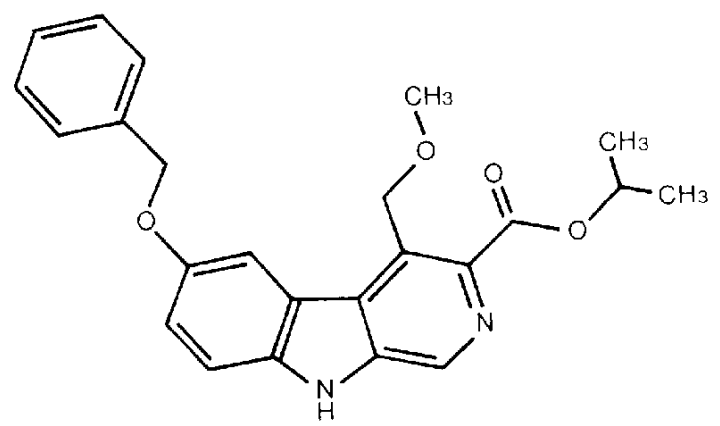

Fig. 1. Chemical structure of abecarnil. 
The $\mathrm{BZ}_{1}$ and $\mathrm{BZ}_{2}$ receptors coexist in the cerebral cortex and hippocampus, but the former is rich in the cerebellum, and the latter is rich in the spinal cord $(10,11)$. The $B Z_{P}$ receptor is abundant in glia cells and many peripheral tissues such as the kidney and lung (8). These subtypes seem to play different functional roles in the brain, but so far their function have not been clarified sufficiently yet.

One purpose of the present study is to characterize the pharmacological activities of abecarnil. Thus the anxiolytic, sedative and ataxic effects of abecarnil in rodents and primates were examined in comparison with those of anxiolytic BZs. The second purpose of the present study is to clarify the interactions of abecarnil with BZ-receptor subtypes. Thus, interactions of abecarnil with rat cerebellar, spinal cord and kidney BZ receptors were examined in comparison with those of drugs acting at $\mathrm{BZ}$ receptors. On the basis of the data on these behavioral and BZ-receptor binding studies, we discuss the mechanism underlying the specific pharmacological activities of the novel anxiolytic abecarnil.

\section{MATERIALS AND METHODS}

\section{Drugs}

Abecarnil, ZK 93426 (ethyl 5-isopropoxy-4-methyl- $\beta$ carboline-3-carboxylate) (Schering AG, Berlin, FRG); diazepam, flumazenil, flunitrazepam (Hoffmann-La Roche, Basel, Switzerland); $\beta$-CCE (ethyl $\beta$-carboline-3-carboxylate: Research Biochemical, Inc., Wayland, MA, USA); GABA (Wako Chemicals, Osaka); bicuculline (Sigma Chemical Co., St. Louis, MO, USA); etizolam (Rize ${ }^{(\mathbb{R})}$ ), clotiazepam (Depas ${ }^{\mathbb{R}}$ ) (Yoshitomi Pharmaceutical Industries, Ltd., Osaka); tofisopam (Grandaxin ${ }^{\mathbb{R}}$ : Mochida Pharmaceutical Co., Ltd., Tokyo) and hexobarbital (Bayer, Leverkusen, FRG) were from the suppliers indicated in parentheses. For the rodents, the test drugs were suspended in a solution containing $0.5 \%$ carboxymethylcellulose- $\mathrm{Na} / 0.04 \%$ Tween $80(\mathrm{~W} / \mathrm{W})$ and administered orally $60 \mathrm{~min}$ prior to the test with an injection volume of 10 $\mathrm{ml} / \mathrm{kg}$ unless otherwise indicated. For the monkeys, drugs were suspended into physiological saline containing $5 \%$ Cremophor EL (Sigma Chemical Co.) and administered intraperitoneally with an injection volume of $1 \mathrm{ml} / \mathrm{kg}$.

\section{Water-lick conflict test in rats}

This test was carried out according to the method of Hjorth et al. (12) with the following modifications. After water-deprivation overnight $(18 \mathrm{hr})$, male Wistar rats (Clea Japan, Inc., Osaka) were allowed to drink 5.5 $(\mathrm{W} / \mathrm{V}) \%$ glucose solution through the spout of the drinking bottle for $5 \mathrm{~min}$ in the test chamber. Then they had a 45-min free-drinking session in their home cage. Animals that had drunk for more than $3 \mathrm{~min}$ at the spout in the test chamber were selected for tests and subjected to water-deprivation overnight $(18 \mathrm{hr})$. On the test day, the animals were allowed to drink the glucose solution through the spout in the test chamber. After consecutive drinking for $10 \mathrm{sec}$, every subsequent drinking attempt was punished with an electric shock applied between the spout and the grid floor ( $2 \mathrm{~mA}$ direct current, delivered for $100 \mathrm{msec}$ every $3 \mathrm{sec}$ ). The number of shocks received during a 5-min test session was recorded.

\section{Effects on foot-shock induced fighting behavior in mice}

Prior to the test, male ICR mice (Clea Japan, Inc.) weighing 18 to $30 \mathrm{~g}$ were fasted for $18 \mathrm{hr}$, with free access to tap water. According to the method of Tedeschi et al. (13), a pair of mice were confined in an acrylic case $(13 \times 13 \times 16 \mathrm{~cm})$ with a steel grid floor and subjected to electric shocks ( $5 \mathrm{HZ}, 2 \mathrm{msec}, 6 \mathrm{~mA}$ ). Each succession of fighting behavior, in which both mice stand on their hind legs, spar and bite at each other, was counted as one fighting episode. Only those pairs that exhibited more than 5 fighting episodes within $3 \mathrm{~min}$ in the control schedule were selected for the test schedule. In the test schedule, 60 min after oral administration of drugs, the fighting behavior was counted for $3 \mathrm{~min}$. For the calculation of the $E D_{50}$ value, the number of pairs exhibiting less than 6 fighting episodes was determined.

\section{Hexobarbital-induced loss of the righting reflex in mice (hexobarbital sleep test)}

Prior to the test, male ddY mice (Clea Japan, Inc.) weighing 19 to $29 \mathrm{~g}$ were fasted for $18 \mathrm{hr}$, with free access to tap water. Each animal was placed gently on its back on a hot plate $\left(32 \pm 2^{\circ} \mathrm{C}\right)$ after intraperitoneal injection of hexobarbital $(70 \mathrm{mg} / \mathrm{kg})$ with an injection volume of 10 $\mathrm{ml} / \mathrm{kg}$. The duration of loss of the righting reflex was measured in each animal.

\section{Traction test in mice}

The traction test was carried out immediately before hexobarbital injection in the tests described above. Each animal was suspended through its fore paws to a metallic wire (2-mm diameter) stretched horizontally at a height of $25 \mathrm{~cm}$. The incidence of ataxia was defined as the percentage of animals that failed to grasp the wire with a hind paw within $10 \mathrm{sec}$.

\section{Behavioral effects in cynomolgus monkeys}

Four male cynomolgus monkeys (Macaca fascicularis: Clea Japan, Inc.), weighing 4 to $7 \mathrm{~kg}$, were housed individually in the standard animal quarters on a $12-\mathrm{hr}$ light-dark cycle. Their diet consisted of standard monkey chow and fresh fruit. Behavioral changes in animals were scored by the method of Wada et al. (14) with some 
Table 1. A list of behaviors in cynomolgus monkeys to assess behavioral effects of abecarnil and diazepam

\begin{tabular}{ll}
\hline Symptoms & Behaviors \\
\hline Belligerence & $\begin{array}{l}\text { angry bark } \\
\text { head lowering } \\
\text { lunging forward } \\
\text { swatting } \\
\text { chattering } \\
\text { mouthing }\end{array}$ \\
Excitement & jumping around \\
& withdrawing \\
Defensiveness & baring teeth \\
& opening mouth \\
Ataxia/Sedation & postural instability \\
& drowsiness \\
\hline
\end{tabular}

modifications, using a rating scale of $0-2(0$; none, 1 : moderate, 2: severe) on the behaviors listed in Table 1. The summed score including excitement, belligerence and defensiveness was defined as an aggression score. The behavioral assessment was carried out up to $4.5 \mathrm{hr}$ after drug administration by an examiner who was unaware of the treatment conditions. Animals were subjected to the drug treatment at 2:00 PM at a one week interval.

\section{$B Z$ binding studies}

Male Wistar rats (Clea Japan, Inc.), weighing 200 to $300 \mathrm{~g}$, were decapitated; and their cerebellum, spinal cord and kidney were dissected. The cerebellum and spinal cord were homogenized at $0-4^{\circ} \mathrm{C}$ in $20 \mathrm{vol}$. of $50 \mathrm{mM}$

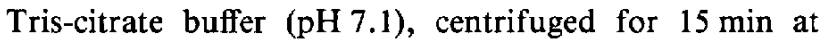
$40,000 \times g$ and washed 3 times. The pellets were frozen and stored at $-30^{\circ} \mathrm{C}$ for more than $18 \mathrm{hr}$ and resuspended in $50 \mathrm{mM}$ Tris- $\mathrm{HCl}$ buffer $(120 \mathrm{mM} \mathrm{NaCl}, 5 \mathrm{mM} \mathrm{KCl}, 2$ $\mathrm{mM} \mathrm{CaCl}, 1 \mathrm{mM} \mathrm{MgCl}_{2}, \mathrm{pH} \mathrm{7.4)}$ for the binding assay. According to the method of Schoemaker et al. (8), the kidney was homogenized at $0-4^{\circ} \mathrm{C}$ in $50 \mathrm{vol}$. of phosphatebuffered saline (181 $\mathrm{mM} \mathrm{Na}^{+}, 9.5 \mathrm{mM} \mathrm{K}^{+}, 50 \mathrm{mM} \mathrm{PO}_{4}{ }^{3-}$, $\mathrm{pH} 7.5$ ) and filtered through 4 layers of sterile gauze.

Cerebellar and spinal cord membrane suspension $(0.5$ $\mathrm{mg}$ protein/tube) was incubated at $37^{\circ} \mathrm{C}$ for $30 \mathrm{~min}$ with $\left[{ }^{3} \mathrm{H}\right]$ flumazenil (New England Nuclear, Boston, MA, USA: $83 \mathrm{Ci} / \mathrm{mmol}$ ) and various concentrations of test drugs in the presence of $100 \mu \mathrm{M}$ GABA or $100 \mu \mathrm{M}$ bicuculline in a final vol. of $2.5 \mathrm{ml}$. Test drugs were dissolved in dimethylsulfoxide (DMSO), and thus the final concentration of DMSO in the assay system was $0.4 \%$ throughout. Then the sample was filtered under vacuum through Whatman GF/B filters followed by three washes, each with $10 \mathrm{ml}$ of the ice-cold buffer. The non-specific binding was defined in the presence of $10 \mu \mathrm{M}$ flunitrazepam. The $K_{d}$ values of $\left[{ }^{3} \mathrm{H}\right.$ ]flumazenil for the cerebellar and spinal cord membranes were $8.8 \mathrm{nM}$ and $7.1 \mathrm{nM}$, respectively. Kidney membrane suspension $(0.2 \mathrm{mg}$ protein/tube) was incubated at $37^{\circ} \mathrm{C}$ for $120 \mathrm{~min}$ with $\left[{ }^{3} \mathrm{H}\right] \mathrm{Ro}$ 5-4864 (New England Nuclear: $81.3 \mathrm{Ci} / \mathrm{mmol}$ ) and various concentrations of test drugs in a final volume of 2.5 $\mathrm{ml}$. Then the sample was filtered under vacuum through Whatman GF/B filters followed by three washes, each with $5 \mathrm{ml}$ of the ice-cold buffer. The non-specific binding was defined in the presence of $100 \mu \mathrm{M}$ diazepam. The $\mathrm{K}_{\mathrm{d}}$ value of $\left[{ }^{3} \mathrm{H}\right] \mathrm{Ro} 5-4864$ was $18 \mathrm{nM}$. The amounts of protein were determined by the method of Lowry et al. (15).

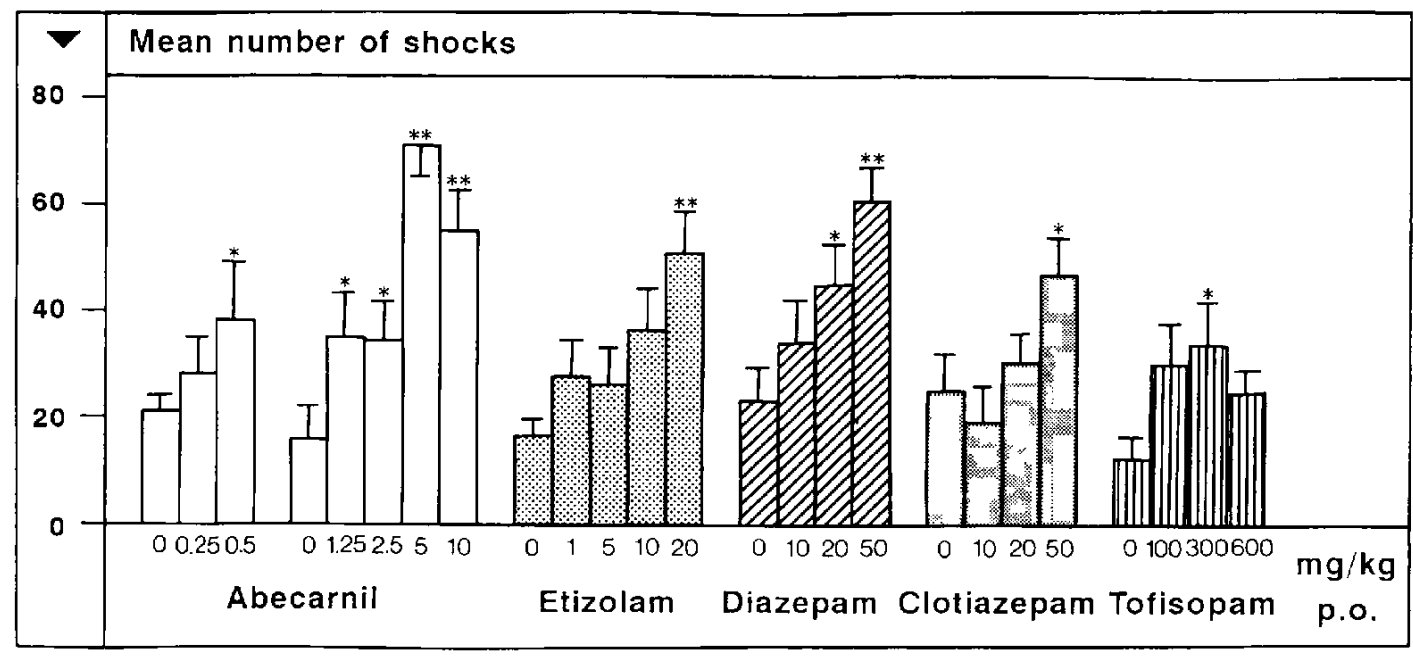

Fig. 2. Effects of abecarnil, etizolam, diazepam, clotiazepam and tofisopam in the water-lick conflict test in rats. Each value represents the mean \pm S.E. of $8-18$ rats. ${ }^{*}: P<0.05,{ }^{* *}: P<0.01$, compared with the control (Dunnett's test). 


\section{Statistical analyses}

Data were expressed as the mean \pm S.E. Values were considered significant when the $P$ value was less than 0.05 by Dunnett's test, Fisher's exact probability test, the Mann-Whitney $U$-test or the unpaired $t$-test as appropriate. The $\mathrm{ED}_{50}$ value ( $95 \%$ confidence limits) was calculated by the log-probit method.

\section{RESULTS}

\section{Effects in the water-lick conflict test of rats}

Anticonflict effects of abecarnil and BZs in rats are shown in Fig. 2. Abecarnil $(0.5-10 \mathrm{mg} / \mathrm{kg})$ induced a significant increase in the number of shocks received $1 \mathrm{hr}$ after oral administration, and the maximal effect was obtained at a dose of $5 \mathrm{mg} / \mathrm{kg}$. Etizolam $(20 \mathrm{mg} / \mathrm{kg})$, diazepam $(20-50 \mathrm{mg} / \mathrm{kg})$, clotiazepam $(50 \mathrm{mg} / \mathrm{kg})$ and tofisopam $(300 \mathrm{mg} / \mathrm{kg})$ also induced a significant increase in the number of shocks. The minimal effective dose of abecarnil was found to be $0.5 \mathrm{mg} / \mathrm{kg}$, p.o., and it was the lowest among those of the drugs tested.

Effects on foot-shock induced fighting behaviors in mice Both abecarnil and diazepam elicited a significant decrease in the number of the foot-shock induced fighting episodes in a dose-dependent manner (Fig. 3). The $\mathrm{ED}_{50}$ values of abecarnil and diazepam were $2.0(0.8-9.0)$ and $0.7(0.3-1.3) \mathrm{mg} / \mathrm{kg}$, p.o., respectively.

Effects on hexobarbital-induced loss of the righting reflex in mice

Abecarnil (10-100 mg/kg, p.o.) slightly prolonged the duration of the hexobarbital-induced loss of the righting

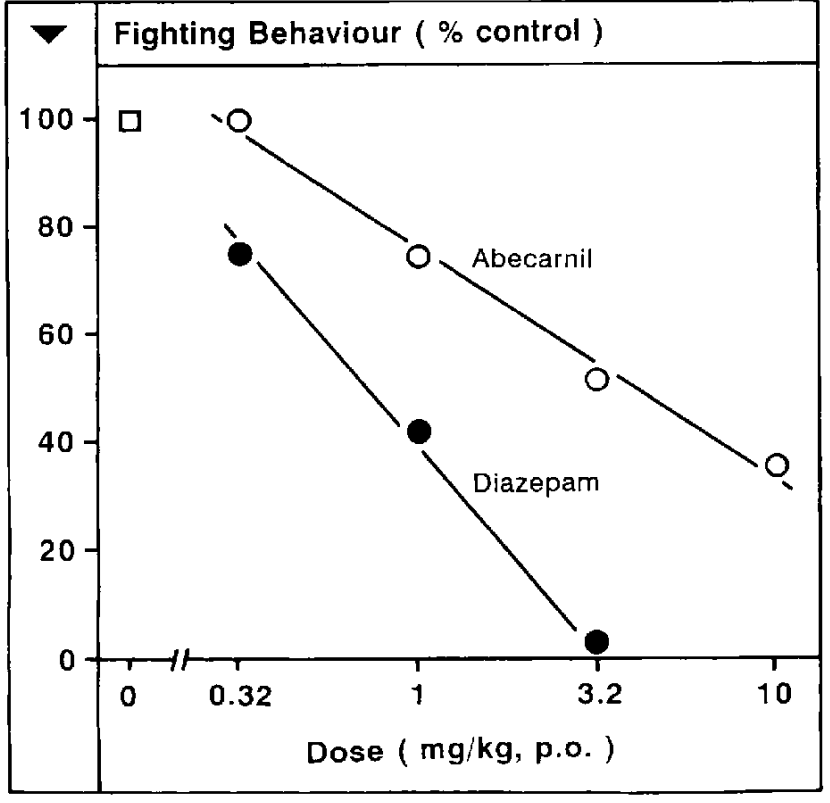

Fig. 3. Effects of abecarnil $(\bigcirc)$ and diazepam $(O)$ on footshock-induced fighting behavior in mice. Each value represents the mean of 6-9 mice. The fighting counts in the vehicle-treatment control ( $\square$ ) was $10.2 \pm 1.2$ (mean \pm S.E.).

reflex, but the effect was not dose-dependent (Fig. 4). On the other hand, BZs tested elicited marked and dose-dependent potentiation of the loss of righting reflex (Fig. 4). The minimal effective dose of abecarnil $(10 \mathrm{mg} / \mathrm{kg}$, p.o.) was higher than those of etizolam (1 $\mathrm{mg} / \mathrm{kg}, \mathrm{p} . \mathrm{o}$.$) , diazep-$ am (3.2 mg/kg, p.o.) and clotiazepam ( $1 \mathrm{mg} / \mathrm{kg}$, p.o.).

Abecarnil $(0.1-1.0 \mathrm{mg} / \mathrm{kg}$, i.p.) alone did not affect the hexobarbital-induced loss of the righting reflex (Fig.

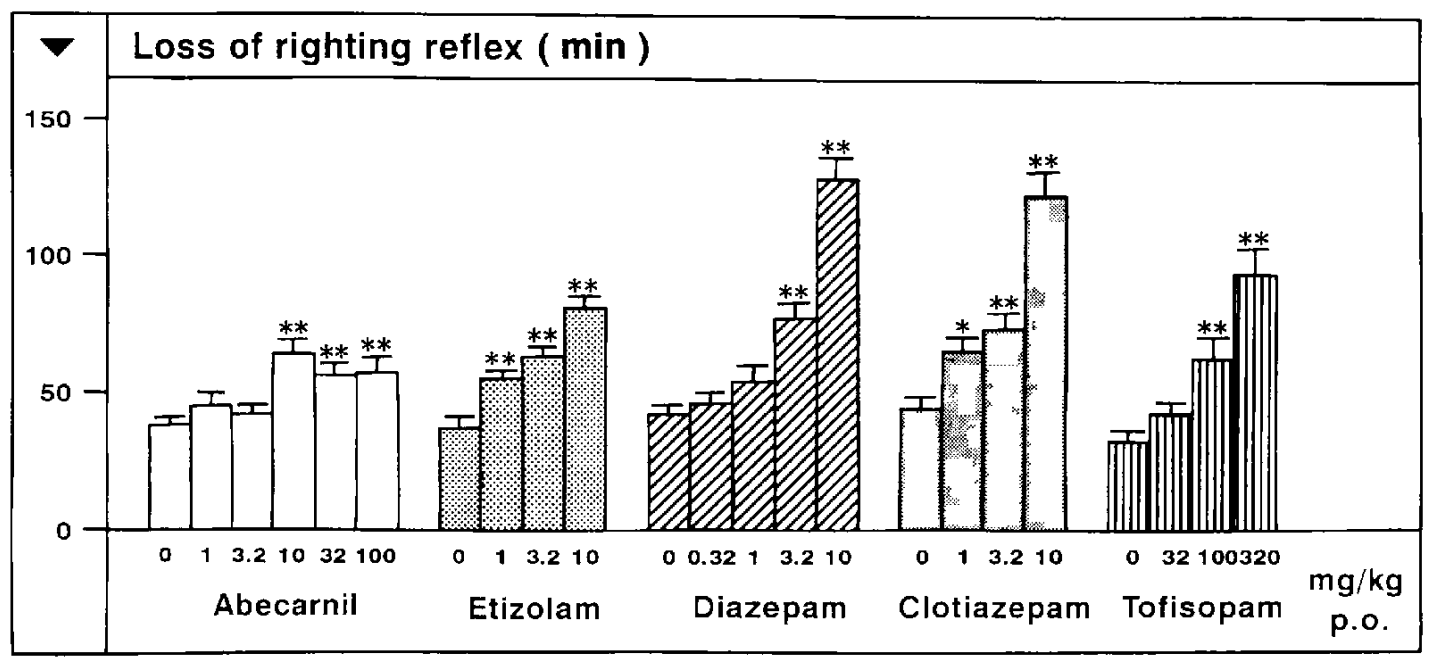

Fig. 4. Effects of abecarnil, etizolam, diazepam, clotiazepam and tofisopam on hexobarbital-induced loss of righting reflex in mice. Each value represents the mean \pm S.E. of $9-20$ mice. ${ }^{*}: \mathrm{P}<0.05,{ }^{* *}: \mathrm{P}<0.01$, compared with the control (Dunnett's test). 


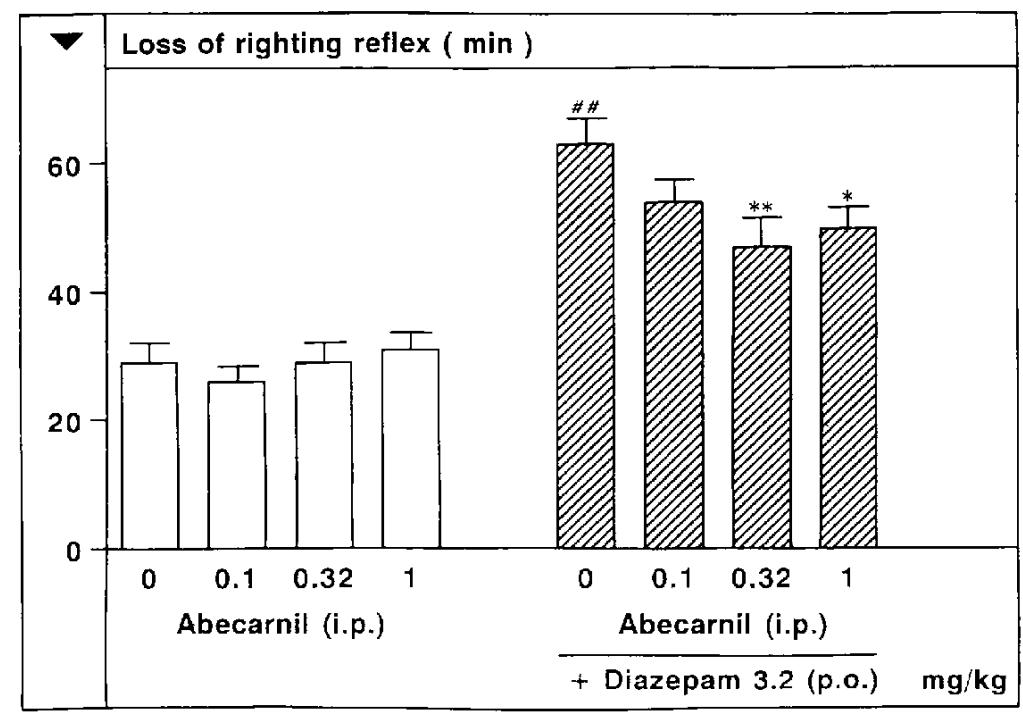

Fig. 5. Antagonism by abecarnil of sedative effects of diazepam on hexobarbital-induced loss of the righting reflex in mice. Each value represents the mean \pm S.E. of $9-10$ mice. ${ }^{*}: \mathrm{P}<0.01$, compared with the non-treatment control; $* \mathrm{P}<0.05$, **: $\mathrm{P}<0.01$, compared with the diazepam-treatment (Dunnett's test).

5). In combination with diazepam $(3.2 \mathrm{mg} / \mathrm{kg}, \mathrm{p} .0$.$) ,$ abecarnil $(0.32-1.0 \mathrm{mg} / \mathrm{kg}$, i.p.) significantly suppressed the diazepam-induced potentiation of the loss of the righting reflex (Fig. 5).

\section{Effects in the traction test in mice}

Abecarnil did not induce any impairment of the motor performance of mice in the traction test up to 100 $\mathrm{mg} / \mathrm{kg}$, p.o. (Fig. 6). On the other hand, the tested BZs impaired the motor performance, giving rise to the $\mathrm{ED}_{50}$ value of $20 \mathrm{mg} / \mathrm{kg}, \mathrm{p} .0$. for etizolam, $9.1 \mathrm{mg} / \mathrm{kg}$, p.o. for diazepam and $8.4 \mathrm{mg} / \mathrm{kg}$, p.o. for clotiazepam. Tofisopam impaired the motor performance in four of ten animals tested at $320 \mathrm{mg} / \mathrm{kg}, \mathrm{p} .0$. In combination with diazepam (10 mg/kg, p.o.), abecarnil ( $32 \mathrm{mg} / \mathrm{kg}$, p.o.) significantly suppressed the impairment induced by diazepam (Fig. 7).

Effects on aggressive behaviors in cynomolgus monkeys

Both abecarnil and diazepam $(3,10 \mathrm{mg} / \mathrm{kg}$, i.p.) suppressed aggressive behaviors including belligerence, excitement and defensiveness in a dose-dependent manner in

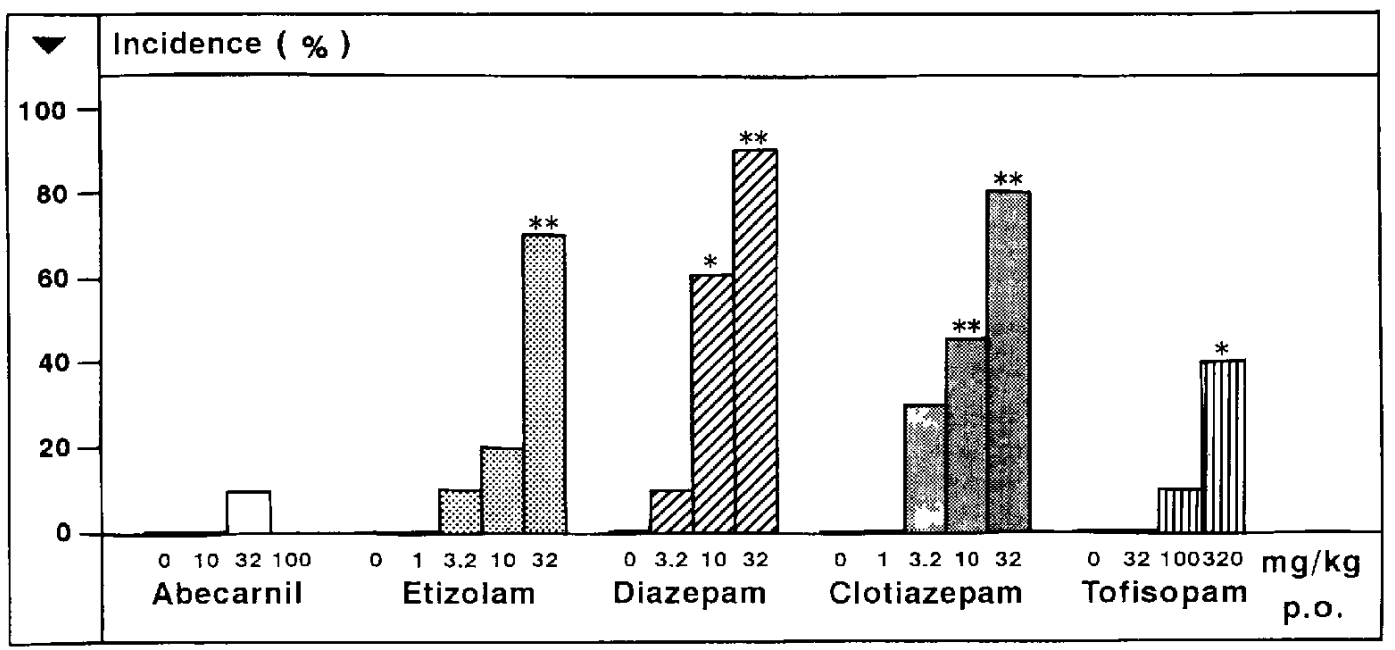

Fig. 6. Effects of abecarnil, etizolam, diazepam, clotiazepam and tofisopam in the traction test in mice. Each value represents the mean \pm S.E. of 8-15 mice. *: $\mathrm{P}<0.05$, **: $\mathrm{P}<0.01$, compared with the control (Fisher's exact probability test). 


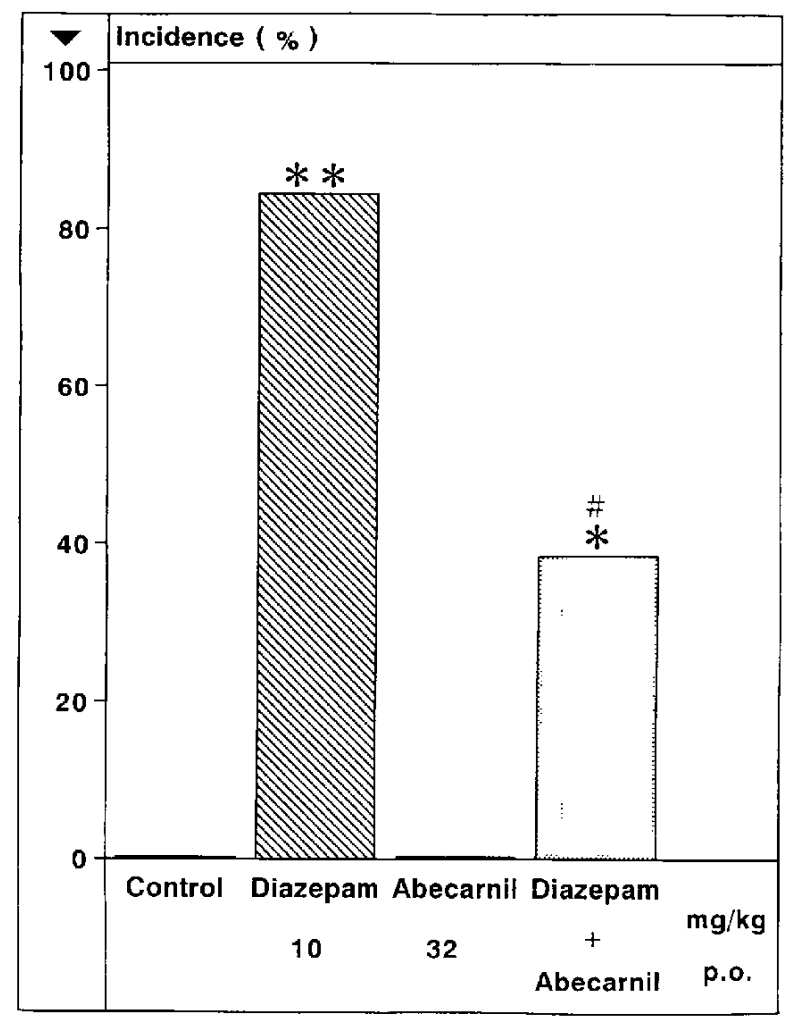

Fig. 7. Antagonism by abecarnil of ataxic effects of diazepam in the traction test in mice. Each value represents the mean $\pm S$.E. of 13 mice. *: $\mathrm{P}<0.05,{ }^{* *}: \mathrm{P}<0.01$, compared with the control; \#: $\mathbf{P}<0.05$, compared with diazepam-treatment (Fisher's exact probability test).
Table 2. Ataxic and sedative effects of abecarnil and diazepam in cynomolgus monkeys

\begin{tabular}{|c|c|c|c|c|}
\hline \multirow{3}{*}{$\begin{array}{l}\text { Treatment } \\
\text { (mg/kg, i.p.) }\end{array}$} & \multicolumn{4}{|c|}{ Ataxia/Sedation } \\
\hline & \multicolumn{2}{|c|}{ postural instability } & \multicolumn{2}{|c|}{ drowsiness } \\
\hline & $0-2$ & $2-4.5$ & $0-2$ & $2-4.5(\mathrm{hr})$ \\
\hline Vehicle & 0 & 0 & 0 & 0 \\
\hline Abecarnil 3 & 0 & 0 & $0.8 \pm 0.5$ & $1.5 \pm 1.2$ \\
\hline 10 & 0 & 0 & $1.0 \pm 0.7$ & $2.0 \pm 1.2$ \\
\hline Diazepam 3 & $0.8 \pm 0.8$ & 0 & $1.0 \pm 1.0$ & $1.3 \pm 1.3$ \\
\hline 10 & $2.0 \pm 0.9^{*}$ & $2.3 \pm 1.3$ & $2.3 \pm 0.8$ & $1.5 \pm 1.2$ \\
\hline
\end{tabular}

Postural instability and drowsiness were scored on a rating scale of 0-2 ( $0:$ none, $1:$ moderate, $2:$ severe). The scores were summed at five time points through 0 - to 2 -hr and 2 - to 4.5 -hr periods after drug- or vehicle-treatment. The value represents a mean score \pm S.E. of four animals. ${ }^{*} \mathrm{P}<0.05$ vs. vehicle-treatment as a control (KruskalWallis analysis followed by Mann-Whitney $U$-test).

cynomolgus monkeys (Fig. 8). The effects of both drugs at $10 \mathrm{mg} / \mathrm{kg}$, i.p. were observed at $30 \mathrm{~min}$ after the administration and lasted for more than $4 \mathrm{hr}$. Abecarnil did not show any postural instability in animals at the tested doses (Table 2). Diazepam induced the marked postural instability in animals at the tested doses (Table 2). Abecarnil as well as diazepam induced drowsiness in animals at the tested doses, but it was not statistically significant (Table 2).

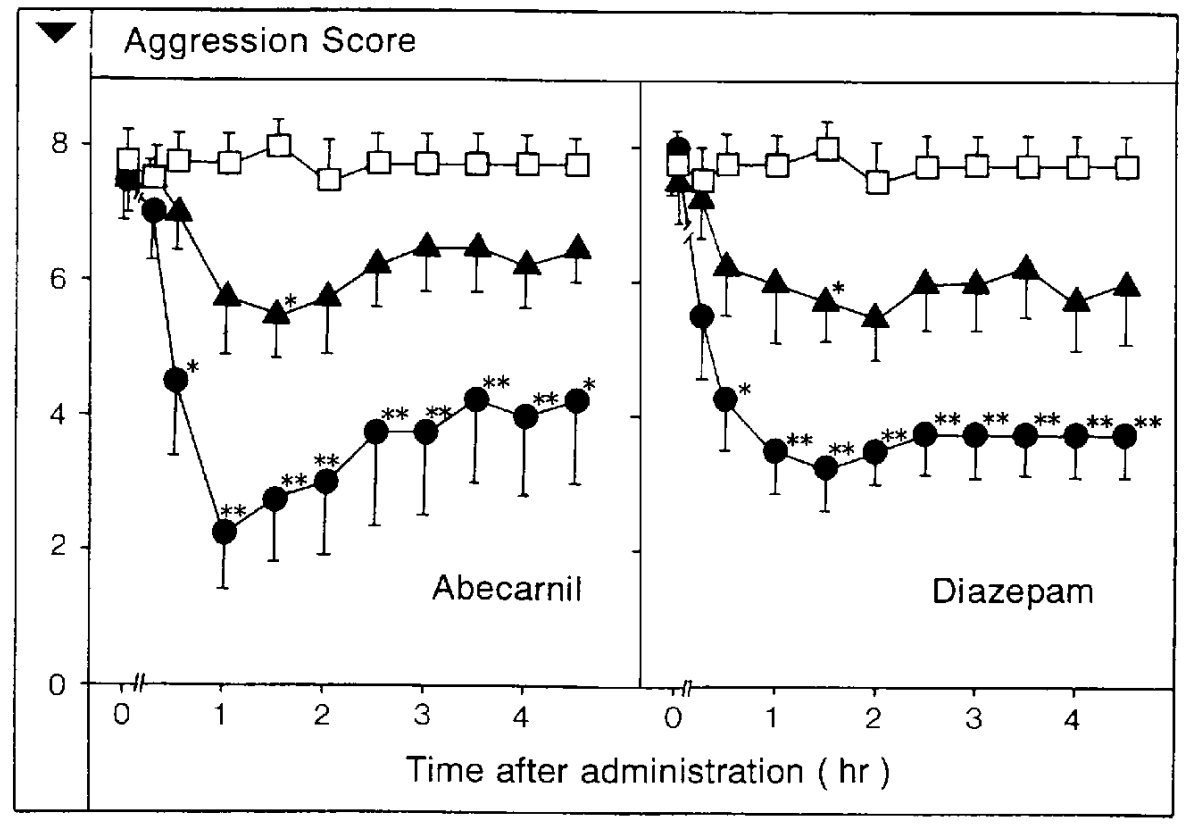

Fig. 8. Effects of abecarnil (left) and diazepam (right) on aggressive behaviors in cynomolgus monkeys. $\square:$ Vehicle; $\boldsymbol{\Delta}: 3$ $\mathrm{mg} / \mathrm{kg}$, i.p.; $: 10 \mathrm{mg} / \mathrm{kg}$, i.p. Each point represents the mean score \pm S.E. of 4 animals. ${ }^{*}: \mathrm{P}<0.05,{ }^{* *}: \mathbf{P}<0.01$, compared with the vehicle-treated control (Dunnett's test). 


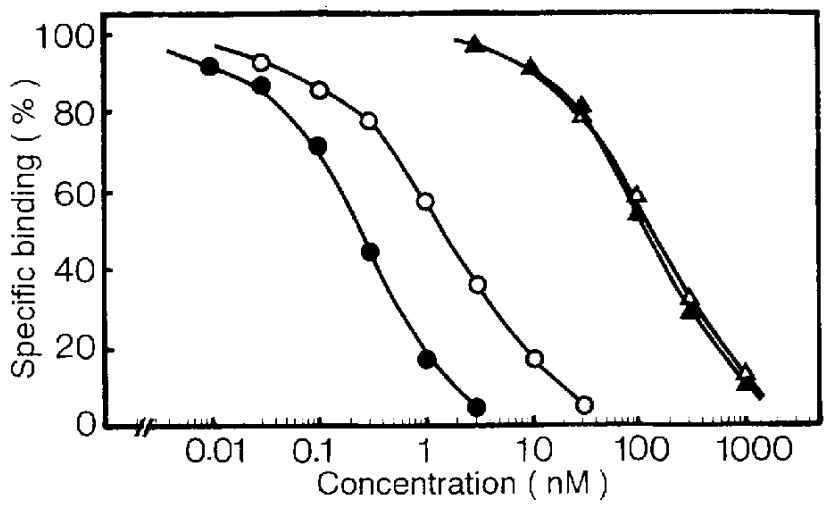

Fig. 9. Displacement by abecarnil and diazepam of $\left[{ }^{3} \mathrm{H}\right]$ flumazenil bindings to rat cerebellar and spinal cord membranes. Abecarnil, cerebellum ( () ), spinal cord $(\bigcirc)$; Diazepam, cerebellum $(\boldsymbol{\Delta})$, spinal cord $(\triangle)$. Each point represents the mean of three independent determinations.

Table 3. Displacements of $\left[{ }^{3} \mathrm{H}\right]$ flumazenil bindings from rat cerebellar and spinal cord membranes and of $\left[{ }^{3} \mathrm{H}\right] \mathrm{Ro} 5-4864$ binding from rat kidney membranes by $\mathrm{BZs}$ and $\beta$-carbolines

\begin{tabular}{lccrlrr}
\hline \multirow{2}{*}{ Drug } & \multicolumn{3}{c}{$\mathrm{K}_{\mathrm{i}}(\mathrm{nM})$} & \multicolumn{2}{c}{$\mathrm{K}_{\mathrm{i}}$ ratio } \\
\cline { 2 - 4 } & Cerebellum & \multicolumn{2}{c}{ Spinal cord } & Kidney & & \\
\hline Flumazenil & 7.6 & 6.3 & $>10000$ & $1: 0.8:>1300$ \\
Flunitrazepam & 29 & 30 & 140 & $1: 1.0:$ & 4.8 \\
Diazepam & 111 & 126 & 360 & $1: 1.1:$ & 3.2 \\
ZK 93426 & 0.35 & 1.1 & 2000 & $1: 3.1: 5700$ \\
3-CCE & 2.6 & 13 & $>10000$ & $1: 5.0:>3800$ \\
Abecarnil & 0.24 & 1.3 & 1200 & $1: 5.4: 5000$ \\
\hline
\end{tabular}

Cerebellar membranes with $0.3 \mathrm{nM}\left[{ }^{3} \mathrm{H}\right]$ flumazenil and spinal cord membranes with $1 \mathrm{nM}\left[{ }^{3} \mathrm{H}\right]$ flumazenil were incubated for $30 \mathrm{~min}$ at $37^{\circ} \mathrm{C}$ in the presence of $100 \mu \mathrm{M}$ bicuculline. Kidney membranes with $1 \mathrm{nM}\left[{ }^{3} \mathrm{H}\right] \mathrm{Ro} 5-4864$ were incubated for $120 \mathrm{~min}$ at $37^{\circ} \mathrm{C}$. Each value is the mean of three independent determinations. $K_{i}$ ratio: ( $K_{\mathrm{i}}$ value in the cerebellum): ( $K_{\mathrm{i}}$ value in the spinal cord): $\left(\mathrm{K}_{\mathrm{i}}\right.$ value in the kidney).

\section{$B Z$ receptors binding}

Abecarnil displaced $\left[{ }^{3} \mathrm{H}\right]$ flumazenil binding to rat cerebellar and spinal cord membranes with much a higher affinity than diazepam (Fig. 9). $\left[{ }^{3} \mathrm{H}\right]$ Flumazenil binding to the cerebellar membranes was displaced by lower concentrations of abecarnil than those required to displace $\left[{ }^{3} \mathrm{H}\right]$ flumazenil binding to spinal cord membranes. (Fig. 9). On the other hand, the displacement curves of diazepam in the cerebellar and spinal cord $\left[{ }^{3} \mathrm{H}\right]$ flumazenil bindings were almost the same (Fig. 9). As shown in Table 3, the $\mathrm{K}_{\mathrm{i}}$ values for flumazenil, flunitrazepam and diazepam were almost the same in the cerebellum and spinal cord. On the other hand, the $K_{i}$ values for abecarnil and $\beta$-CCE in the cerebellum were five times lower than those in the spinal

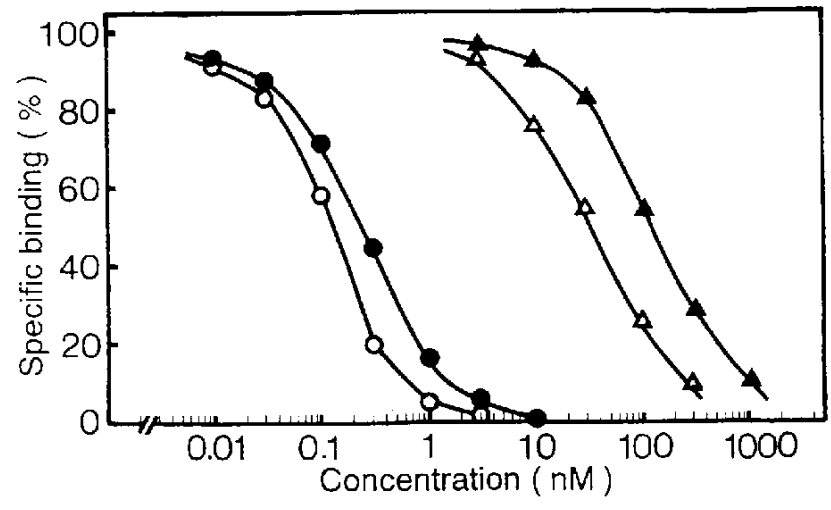

Fig. 10. Displacement by abecarnil and diazepam of $\left[{ }^{3} \mathrm{H}\right]-$ flumazenil bindings to rat cerebellar membranes in the presence or absence of GABA. Abecarnil in the presence $(O)$ or absense $(O)$ of $100 \mu \mathrm{M}$ GABA; Diazepam in the presence $(\triangle)$ or absence $(\Delta)$ of $100 \mu \mathrm{M}$ GABA. Each point represents the mean of three independent determinations.

Table 4. GABA-ratios of BZs and $\beta$-carbolines for the displacement of $\left[{ }^{3} \mathrm{H}\right]$ flumazenil bindings from rat cerebellar and spinal cord membranes

\begin{tabular}{lll}
\hline \multirow{2}{*}{ Drug } & \multicolumn{2}{c}{ GABA-ratio } \\
\cline { 2 - 3 } & Cerebellum & Spinal cord \\
\hline Diazepam & $3.25 \pm 0.10^{*}$ & $4.36 \pm 0.40^{*}$ \\
Flunitrazepam & $2.63 \pm 0.22^{* \#}$ & $5.05 \pm 0.76^{*}$ \\
Abecarnil & $1.89 \pm 0.20^{* \hbar}$ & $2.84 \pm 0.35^{* *}$ \\
Flumazenil & $1.23 \pm 0.06^{*}$ & $1.18 \pm 0.08^{*}$ \\
ZK 93426 & $0.98 \pm 0.20^{*}$ & $1.02 \pm 0.03^{* \#}$ \\
$\beta$-CCE & $0.57 \pm 0.09^{* \#}$ & $0.62 \pm 0.10^{* \#}$ \\
\hline
\end{tabular}

GABA-ratio: ( $\mathrm{IC}_{50}$ in the presence of $100 \mu \mathrm{M}$ bicuculline) $/\left(\mathrm{IC}_{50}\right.$ in the presence of $100 \mu \mathrm{M}$ GABA). Each value is the mean \pm S.D. of three or four independent determinations. ${ }^{*}: \mathbf{P}<0.05$ vs. diazepam, \#: $\mathrm{P}<0.05$ vs. flumazenil (Unpaired $t$-test).

cord. Abecarnil, like $\beta$-CCE and ZK 93426, displaced $\left[{ }^{3} \mathrm{H}\right] \mathrm{Ro}$ 5-4864 binding to rat kidney membranes with a lower affinity than diazepam and flunitrazepam (Table 3).

Whereas the affinity of diazepam for $\left[{ }^{3} \mathrm{H}\right]$ flumazenil binding sites in rat cerebellum was markedly enhanced in the presence of $100 \mu \mathrm{M}$ GABA, the affinities of abecarnil for these receptors was slightly enhanced in the same condition (Fig. 10). The GABA ratios of BZs and $\beta$-carbolines in the cerebellum and spinal cord are summarized in Table 4. The GABA ratios of abecarnil were 1.9 in the cerebellum and 2.8 in the spinal cord, and they were smaller than those of diazepam and flunitrazepam, but higher than those of the $\mathrm{BZ}$ antagonists, flumazenil and ZK 93426. 


\section{DISCUSSION}

It has been reported that intraperitoneal administration of abecarnil shows potent anxiolytic activities in rodent models (1). In the present study, oral administration of abecarnil $(0.5-10 \mathrm{mg} / \mathrm{kg})$ caused a significant increase in the number of shocks in the water-lick conflict test with rats. The minimal effective dose was found to be lower than those of anxiolytic BZs such as etizolam, diazepam, clotiazepam and tofisopam. Abecarnil, like diazepam, showed taming effects to suppress fighting and aggressive behaviors in mice and monkeys. These results again indicate that abecarnil may exhibit a potent anxiolytic activity clinically.

Despite its potent anxiolytic activity, abecarnil induced only slight effects in tests of sedation and ataxia. The efficacy of abecarnil on potentiating hexobarbital-induced loss of the righting reflex in mice was much weaker than that of the tested BZs. In the traction test, abecarnil failed to impair the motor performance of mice up to 100 $\mathrm{mg} / \mathrm{kg}$, p.o., whereas the tested BZs induced the marked impairment. Furthermore, abecarnil antagonized diazepam-induced sedative and ataxic effects in these tests. Also in monkeys, abecarnil $(3,10 \mathrm{mg} / \mathrm{kg}$, i.p.) suppressed aggressive behaviors without induction of drowsiness and postural instability, whereas diazepam $(3,10 \mathrm{mg} / \mathrm{kg}$, i.p.) induced postural instability associated with the suppressive effects. Taken together with the behavioral studies in rodents and primates, abecarnil was found to show anticonflict and taming effects in rodents and primates at doses eliciting little sedative and ataxic effects in contrast to diazepam which shows both effects.

As is common with $\beta$-carbolines, abecarnil had a very high affinty for central BZ receptors but a low affinity for peripheral $\mathrm{BZ}_{\mathrm{P}}$ receptors, suggesting that it exhibits its pharmacological action through central $\mathrm{BZ}$ receptors. Abecarnil displaced $\left[{ }^{3} \mathrm{H}\right]$ flumazenil binding from rat cerebellar $\mathrm{BZ}$ receptors $\left(\mathrm{K}_{\mathrm{i}}=0.24 \mathrm{nM}\right)$ with about a five times higher affinity than that from spinal cord $\mathrm{BZ}$ receptors $\left(\mathrm{K}_{\mathrm{i}}=1.3 \mathrm{nM}\right)$, which was in contrast to $\mathrm{BZs}$ such as flunitrazepam and diazepam, which show low affinity and no selectivity for these receptors. In the previous studies $(8,9)$, it has been shown that the $\mathrm{BZ}$ receptors in the cerebellum and spinal cord are predominantly of the $\mathrm{BZ}_{1^{-}}$ and the $\mathrm{BZ}_{2}$-receptor subtypes, respectively. In our study, it was ascertained that zolpidem (data not shown) and $\beta$-CCE, $\mathrm{BZ}_{1}$-selective ligands $(6,10)$, had about five times higher affinities for the $\mathrm{BZ}$ receptors in the cerebellum than those in the spinal cord. The physiological roles of the $\mathrm{BZ}_{1}$ and $\mathrm{BZ}_{2}$ receptors in brain function are not yet clarified, but the sedative and ataxic effects by BZs have been proposed to be due to the over activation of the $\mathrm{BZ}_{1}$ and $\mathrm{BZ}_{2}$ receptors, respectively $(16-18)$. Findings that abecarnil had no ataxic effects may be partly due to its lower affinity for spinal cord $\mathbf{B Z}_{2}$ receptors, but it does not explain the antagonism of diazepam-induced ataxia.

Binding of central BZ-receptor ligands is influenced by the presence of a GABA agonist $(17,19,20)$. Thus, the binding of $\mathrm{BZ}$ agonists is potentiated in the presence of muscimol or GABA, while the opposite is true for the inverse agonists showing anxiogenic and proconvulsive effects. The binding of $\mathrm{BZ}$ antagonists remains unchanged irrespective of the presence of GABA. Therefore, the GABA ratio can be used as an index showing the intrinsic activity of $\mathrm{BZ}$-receptor ligands at the $\mathrm{GABA}_{\mathbf{A}}$ /BZ receptor complex $(17,19,20)$. In the present study, the GABA ratios of abecarnil at cerebellar and spinal cord $\mathrm{BZ}$ receptors were fell between those of the agonists (diazepam and flunitrazepam) and the antagonists (flumazenil and ZK 93426). Thus, abecarnil may be interpreted as a partial agonist at both the $\mathrm{BZ}_{1}$ and $\mathrm{BZ}_{2}$ receptors (at least at the receptors in the cerebellum and spinal cord). A' partial agonist for the BZ receptors has been reported to be able to block some of the effects elicited by the full agonist (21). The findings that abecarnil showed only weak sedative effects and inhibited the effects induced by diazepam may be consistent with its $\mathrm{BZ} Z_{1}$ partial agonist characterization. The partial agonistic action of abecarnil at spinal cord $\mathrm{BZ}_{2}$ receptors may be supported by the antagonism of diazepam-induced ataxia, which seemed to result from displacing of diazepam from the receptors.

Recently, possible molecular substrates for the BZreceptor heterogeneity have been provided by the cloning of cDNAs encoding multiple isoforms of $\alpha, \beta$ and $\gamma$ subunits that are thought to constitute the $\mathrm{GABA}_{\mathrm{A}}$-receptor complex (22). In the different $\alpha$-isoform coexpressed with $\hat{\beta}_{1}$ and $\gamma_{2}$ in mammalian cells, the receptors containing the $\alpha_{1}$-subunit displayed the properties of $\mathbf{B Z}_{1}$ receptors whilst the receptors containing $\alpha_{2}-, \alpha_{3}$ - or $\alpha_{5}$-subunits displayed the properties of $\mathrm{BZ}_{2}$ receptors $(23,24)$. Thus, our present studies suggest that abecarnil may be a selective ligand for the $\mathrm{GABA}_{\mathrm{A}}$ receptor containing the $\alpha_{1}$-subunit, which is consistent with the preliminary evidence on recon-

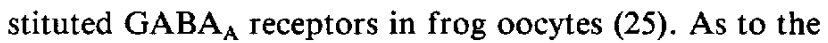
intrinsic activity, the GABA ratio is likely to represent the average intrinsic activity for a given substance at a variety of $\mathrm{GABA}_{\mathrm{A}} / \mathrm{BZ}$ receptors. Thus, our present findings suggest that abecarnil may be a partial agonist at GABA $_{A}$ $/ \mathrm{BZ}$ receptors containing the $\alpha_{1}$-subunit, and the average intrinsic activity of abecarnil at a mixture of $\mathrm{GABA}_{\mathrm{A}} / \mathrm{BZ}$ receptors containing $\alpha_{2^{-}}, \alpha_{3^{-}}$and $\alpha_{5^{-}}$-subunits may be weaker than that of conventional BZs.

In conclusion, in contrast to the $\mathrm{BZ}$ derivatives, abecarnil may act as a selective partial agonist at central $\mathrm{BZ}_{1}$ receptors, resulting in its potent anticonflict and taming 
effects with little sedative and ataxic effects. Thus, Abecarnil might offer a new therapeutic tool for the treatment of anxiety with less side effects in place of conventional BZ anxiolytics.

\section{Acknowledgment}

We thank Dr. D.N. Stephens (Schering AG, Berlin) for his advice on the preparation of this manuscript.

\section{REFERENCES}

1 Stephens DN, Schneider HH, Kehr W, Andrews JS, Rettig K-J, Turski L, Schmiechen R, Turner JD, Jensen LH, Petersen EN, Honoré $\mathrm{T}$ and Hansen JB: Abecarnil, a metabolically stable, anxioselective $\beta$-carboline acting at benzodiazepine receptors. J Pharmacol Exp Ther 253, 334-343 (1990)

2 Turski L, Stephens DN, Jensen LH, Petersen EN, Meldrum BS, Patel S, Hansen JB, Löscher W, Schneider HH and Schmiechen R: Anticonvulsant action of the $\beta$-carboline abecarnil: Studies in rodents and baboon, Papio papio. J Pharmacol Exp Ther 253, 344-352 (1990)

3 Stephens DN, Turski L, Hillman M, Turner JD, Schneider HH and Yamaguchi M: What are the differences between abecarnil and conventional benzodiazepine anxiolytics? In GABAergic Synaptic Transmission, Edited by Biggio G, Concas A and Costa E, pp 395-405, Raven Press, New York (1992)

4 Haefely W, Martin JR and Schoch P: Novel anxiolytics that act as partial agonists at benzodiazepine receptors. Trends Pharm Sci 11, $452-456$ (1990)

5 Löscher W, Hönack D, Scherkl R, HashemA and Frey H: Pharmacokinetics, anticonvulsant efficacy and adverse effects of the $\beta$-carboline abecarnil, a novel ligand for benzodiazepine receptors, after acute and chronic administration in dogs. J Pharmacol Exp Ther 255, 541-548 (1990)

6 Benavides J, Peny B, Dubois A, Perrault G, Morel E, Zivcovic $B$ and Scatton B: In vivo interaction zolpidem with central benzodiazepine (BZD) binding sites (as labeled by $\left[{ }^{3} \mathrm{H}\right]$ Ro 15-1788) in the mouse brain. Preferential affinity of zolpidem for the $\omega_{1}$ (BZD1) subtype. J Pharmacol Exp Ther 245, $1033-1040$ (1988)

7 Klepner CA, Lippa AS, Benson DI, Sano MC and Beer B: Resolution of two biochemically and pharmacologically distinct benzodiazepine receptors. Pharmacol Biochem Behav 11, 457-462 (1979)

8 Schoemaker H, Boles RG, Horst WD and Yamamura HI: Specific high-affinity binding sites for $\left[{ }^{3} \mathrm{H}\right] \mathrm{Ro} 5-4864$ in rat brain and kidney. J Pharmacol Exp Ther 225, 61-69 (1983)

9 Dennis T, Dubois A, Benavides J and Scatten B: Distribution of central $\omega_{1}$ (Benzodiazepine 1 ) and $\omega_{2}$ (Benzodiazepine 2) receptor subtypes in the monkey and human brain. Autoradiographic study with $\left[{ }^{3} \mathrm{H}\right]$ flunitrazepam and the $\omega_{1}$ selective ligand $\left[{ }^{3} \mathrm{H}\right]-$ zolpidem. J Pharmacol Exp Ther 247, 309- 341 (1988)

10 Braestrup $C$ and Nielsen $\mathrm{M}$ : $\left[{ }^{3} \mathrm{H}\right]$ Propyl- $\beta$-carboline-3-carboxylate as a selective radioligand for the BZ1 benzodiazepine receptor subclass. J Neurochem 37, 333-341 (1981)

11 Watanabe Y, Khatami S, Shibuya T and Salafsky B: Ontogenetic properties of benzodiazepine receptor subtypes in rat spinal cord. Eur J Pharmacol 109, 307-309 (1985)

12 Hjorth S, Engel JA and Carlsson A: Anticonflict effects of low doses of the dopamine agonist apomorphine in the rat. Pharmacol Biochem Behav 24, 237-240 (1986)

13 Tedeschi RE, Tedeschi DH, Mucha A, Cook K, Mattis PA and Fellows EJ: Effects of various centrally acting drugs on fighting behavior of mice. J Pharmacol Exp Ther 125, 28-34 (1959)

14 Wada T, Nakajima R, Kurihara E, Narumi S, Masuoka Y, Goto G, Saji $Y$ and Fukuda N: Pharmacologic characterization of a novel non-benzodiazepine selective anxiolytic, DN-2327. Jpn J Pharmacol 49, 337-349 (1989)

15 Lowry $\mathrm{OH}$, Rosebrough NJ, Farr AL and Randall RJ: Protein measurement with the Folin phenol reagent. J Biol Chem 193, $265-275$ (1951)

16 Arbilla S, Allen J, Wick A and Langer SZ: High affinity $\left[{ }^{3} \mathrm{H}\right]$ zolpidem binding in the rat brain: an imidazopyridine with agonist properties at central benzodiazepine receptors. Eur J Pharmacol 130, 257-263 (1986)

17 Ozawa M, Nakada Y, Sugimachi K, Akai T and Yamaguchi M: Interaction of the hypnotic lormetazepam with central benzodiazepine receptor subtypes $\omega_{1}, \omega_{2}$ and $\omega_{3}$. Folia Pharmacol Jpn 98, 399-408 (1991) (Abstr in English)

18 Hirouchi M, Mizutani $\mathrm{H}$, Kohno $\mathrm{Y}$ and Kuriyama $\mathrm{K}$ : Characteristics of the association of brotizolam, a thieno-triazolo diazepine derivative, with the benzodiazepine receptor: a selective and high affinity ligand of the central type I benzodiazepine receptor. Jpn J Pharmacol 59, 387-391 (1992)

19 Ehlert FJ, Roeske WR, Gee KW and Yamamura HI: An allosteric model for benzodiazepine receptor function. Biochem Pharmocol 32, 2375-2383 (1985)

20 Wood PL, Loo P, Braunwaider A, Yokoyama N and Cheney DL: In vitro characterization of benzodiazepine receptor agonists, antagonists and inverse agonists and agonist/antagonists. J Pharmacol Exp Ther 231, 572-576 (1984)

21 Schneider $\mathrm{HH}$, Turski $\mathrm{L}$ and Stephens DN: Modulation of the GABA $_{\mathrm{A}}$ receptor complex. In GABA: Basic Research and Clinical Applications, Edited by Bowery NG and Nistico G, pp $102-134$, Pythagora Press, Rome and Milan (1989)

22 Olsen RW and Tobin AJ: Molecular biology of GABA A recep- $^{-}$ tors. FASEB J 4, 1469 - 1480 (1990)

23 Pritchett DB, Luddens $\mathbf{H}$ and Seeburg PH: Type I and type II GABA $_{A}$-benzodiazepine receptors produced in transfected cells. Science 245, 1389-1392 (1989)

24 Pritchett DB and Seeburg PH: $\gamma$-Aminobutyric acid $_{\mathrm{A}}$ receptor $\alpha_{s}$-subunit creates novel type II benzodiazepine receptor pharmacology. J Neurochem 54, 1802 - 1804 (1990)

25 Pribilla I, Neuhaus R, Hillman M, Turner J, Stephens DN and Schneider HH: Abecarnil is a full agonist at some, and a partial agonist at other recombinant $\mathrm{GABA}_{\mathrm{A}}$ receptor subtypes. In Anxiolytic $\beta$-Carbolines: From Molecular Biology to the Clinic, Edited by Stephens DN, pp 50-61, Springer Verlag, Heidelberg (1993) 